\title{
Wild ornamental germplasm exploration and domestication based on biotechnological approaches. In vitro colchicine treatment to obtain a new cultivar of Scoparia montevidiensis
}

\author{
Alejandro S. Escandón* \\ Instituto de Floricultura \\ Instituto Nacional de Tecnologia Agropecuaria (INTA) \\ INTA Castelar, De los Reseros y Las Cabañas s/n. 1712 \\ Pcia. Buenos Aires, Argentina \\ Tel/Fax: 541146219475 \\ E-mail: aescandon@castelar.inta.gov.ar \\ Ikuo Miyajima\# \\ Centro Tecnológico de Flori, Fruti y Horticultura of \\ Japan International Cooperation Agency in Argentine (JICA-CETEFFHO) \\ INTA Castelar, De los Reseros y Las Cabañas s/n. 1712 \\ Pcia. Buenos Aires, Argentina \\ Tel/Fax: 541146219475 \\ E-mail:cxx00130@nifty.com

\section{Marisol Alderete} \\ Instituto de Floricultura \\ Instituto Nacional de Tecnologia Agropecuaria (INTA) \\ INTA Castelar, De los Reseros y Las Cabañas s/n. 1712 \\ Pcia. Buenos Aires, Argentina \\ Tel/Fax: 541146219475 \\ E-mail: limarial@hotmail.com

\section{Juan Carlos Hagiwara} \\ Instituto de Floricultura \\ Instituto Nacional de Tecnologia Agropecuaria (INTA) \\ INTA Castelar, De los Reseros y Las Cabañas s/n. 1712 \\ Pcia. Buenos Aires, Argentina \\ Tel/Fax: 541146219475 \\ E-mail: jhagiwara@cnia.inta.gov.ar

\section{Gabriela Facciuto} \\ Instituto de Floricultura \\ Instituto Nacional de Tecnologia Agropecuaria (INTA) \\ INTA Castelar, De los Reseros y Las Cabañas s/n. 1712 \\ Pcia. Buenos Aires, Argentina \\ Tel/Fax: 541146219475 \\ E-mail: gfacciuto@cnia.inta.gov.ar

\section{Diego Mata} \\ Instituto de Floricultura \\ Instituto Nacional de Tecnologia Agropecuaria (INTA) \\ INTA Castelar, De los Reseros y Las Cabañas s/n. 1712 \\ Pcia. Buenos Aires, Argentina \\ Tel/Fax: 541146219475 \\ E-mail:dmata@cnia.inta.gov.ar

\section{Silvina M. Soto} \\ Instituto de Floricultura \\ Instituto Nacional de Tecnologia Agropecuaria (INTA) \\ INTA Castelar, De los Reseros y Las Cabañas s/n. 1712 \\ Pcia. Buenos Aires, Argentina \\ Tel/Fax: 541146219475 \\ E-mail: ssoto@cnia.inta.gov.ar
}

*Corresponding author 
Financial support: The present work was supported by the INTA JICA agreement, project: Argentina Floriculture Development.

Keywords: chimera, flow cytometry, micropropagation, ornamental plants, tetraploid.

"Present address: Institute of Tropical Agriculture, Kyushu University, Fukuoka 812-8581, Japan.

Abbreviations:

BAP- 6: benzyl amino purine;

DMSO: dimethylsulfoxide;

MS: Murashige and Skoog (1962);

NAA: naphthalene acetic acid.

The genus Scoparia is native from Argentina. The diversity of colours and shape of their flowers bestows this genus a very interesting ornamental potential. The purpose of the present study is to explore the Scoparia species germplasm by means of in vitro polyploidization in order to improve their ornamental qualities. Accessions of $\boldsymbol{S}$. montevidiensis var. montevidiensis, $\boldsymbol{S}$. montevidiensis var. glandulifera, $S$. nudicaulis, $S$. hasleriana and $S$. dulcis were collected and maintained under greenhouse conditions. The Murashige-Skoog medium, supplemented with $0.25 \mathrm{mg} / \mathrm{L}$ BAP was used for the nodal segments multiplication of the five Scoparia species. Except for $S$. hasleriana, the multiplication rate of the other species ranged between 10 and 12 shoots per explant. The colchicine doses tested with $S$. montevidiensis were: $0.0 ; 0.1 ; 0.05 ; 0.01$ and 0.001 ( 24 and $48 \mathrm{hrs}$ ). From a total of 364 recovered plants, 4 solid tetraploid and 16 chimeras were detected. Significant differences were observed for the size of flower, leaves, and the stem diameter among the tetraploid plants and between them and the control. The tissue culture proved to be a powerful tool both to multiply the Scoparia material incorporated to our germplasm collection and to obtain new improved varieties of this beautiful genus.

The genus Scoparia belongs to family of the Scrophulariacea. So far, 10 native species from Argentina were described, five of which (1: S. montevidiensis var. montevidiensis; 2: S. montevidiensis var. glandulifera; $3: S$. nudicaulis; 4: S. hasleriana; and 5: S. dulcis) are widespread species in the temperate regions of Argentina, mainly in the provinces of the Mesopotamia region, in the north east of the country (Zuloaga and Morrone, 1999).

This genus shows an interesting diversity in shapes and colors of the flowers, as well as different growth habits. For instance, $S$. montevidiensis var. montevidiensis, $S$. montevidiensis var. glandulifera, $S$. nudicaulis, $S$. hasleriana are herbaceous plants, whereas $S$. dulcis is a sub shrubby plant, and both varieties present a profuse growth with abundant yellow blossom. S. dulcis has white flowers, and the flowers of $S$. hasleriana and $S$. nudicaulis are sky blue. However, flower size represents a problem in terms of their potential commercial value because in all of five Scoparia species they are too small. The development of polyploids can be a useful and valuable tool to improve this trait in breeding programs (Notzuka et al. 2000).

Polyploidization was used successfully to increase the size of flowers, intensify the colours of leaves and flowers, modify plant shape and restore fertility in ornamental species (Horn, 2002).

Tissue culture using colchicine treatment is an interesting biotechnological alternative tool for the domestication and early exploration of wild germplasm with ornamental potential. In the present study we describe the in vitro micropropagation protocol for four species (five different accessions) of Scoparia spp, as well as the development of a new variety of $S$. montevidiensis using in vitro colchicine polyploidization as a breeding tool.

\section{MATERIALS AND METHODS}

\section{Tissue culture}

Nodal segments of $S$. montevidiensis var. glandulifera were first sonicated during $20 \mathrm{~min}$ and then disinfected by immersion in $70 \%$ ethanol for $1 \mathrm{~min}$ and then in a solution containing $25 \%$ sodium hypochlorite: $0.01 \%$ Tween 80 during $25 \mathrm{~min}$. Finally they were rinsed three times with distilled and sterile water.

The explants were cultured onto a hormone free MS medium (Murashige and Skoog, 1962) and served as a source for the explant used to study the behaviour of $S$. montevidiensis var. glandulifera under different hormones combinations. The medium used for the culture of the nodal segments was MS supplemented with $20 \mathrm{~g} / \mathrm{L}$ sucrose, $7 \mathrm{~g} / \mathrm{L}$ agar, and the following growth regulator concentrations: $0.0 ; 0.25 ; 0.5$ and $1.00 \mathrm{mg} / \mathrm{L}$ NAA and BAP, in all possible combination. The $\mathrm{pH}$ was adjusted to 5.7 with $\mathrm{KOH}$. The photoperiod was 16:8 under an irradiance of 3,000 lux. The recovered shoots were transferred monthly to the same fresh medium except for the rooting step. Three or four centimetres length plantlets were transferred to the rooting medium (MS hormone free). The rooted plants were acclimatized according to Escandón et al. (2003), that is, the rooted plants were transferred to an $8.0 \mathrm{~cm}$ diameter pot containing Growing $\operatorname{mix}{ }^{\circledR}$, and they were maintained inside the humidity chamber. The nylon bags used to make the humidity chamber were gently perforated once per day until no condensation was detected inside them. This 
Table 1. Nodal segments response of $S$. montevidiensis var. glandulifera toward different combination of NAA/BAP.

\begin{tabular}{|c|c|c|c|c|}
\hline \multirow{2}{*}{$\begin{array}{l}\text { NAA } \\
(\mathrm{mg} / \mathrm{l})\end{array}$} & \multicolumn{4}{|c|}{ BAP (mg/l) } \\
\hline & 0.0 & 0.25 & 0.5 & 1.0 \\
\hline 0.0 & $\mathbf{S}(2.25 \pm 0.42)^{a}$ & $\begin{array}{c}S(9.04 \pm 0.41)^{c} \\
\text { Cc }\end{array}$ & $\mathbf{S}(3.42 \pm 0.41)^{\mathrm{ab}} \mathrm{Cc}$ & $\mathbf{S}(4.42 \pm 0.41)^{\mathrm{ab}} \mathbf{V t}$ \\
\hline 0.25 & Fc & Fc & $\mathrm{Cc}$ & Cc \\
\hline 0.5 & Fc & Fc & $\mathrm{Cc}$ & Cc \\
\hline 1.0 & Fc & Fc & Cc & Cc \\
\hline
\end{tabular}

S: shoot. Fc: friable callus. Cc: compact callus. Vt: vitrified tissue.

Bold letters indicate the main response for each treatment. The numbers in the brackets indicate number of shoots per explant (means \pm SD of two replications) of the shoots recovered in each treatment. The same letter indicates no significance differences between treatments.

feature determined the end of the acclimatization stage. Afterwards, the plants were grown under greenhouse conditions. The number of explant was 20 per treatment and the experiment was repeated twice.

\section{In vitro multiplication of five Scoparia species}

Nodal segments (length: $0.5 \mathrm{~cm}$ ) from five species of Scoparia: S. hasleriana, S. dulcis, S. nudicaulis, $S$. montevidiensis var. montevidiensis, and $S$. montevidiensis var. glandulifera, were disinfected, and cultured on MS medium hormone free as was described bellow. The micro cuttings were obtained from the in vitro developed plantlets and they were transferred to a MS medium supplemented with $20 \mathrm{~g} / \mathrm{L}$ sucrose, $7 \mathrm{~g} / \mathrm{L}$ agar and $0.25 \mathrm{mg} / \mathrm{L}$ BAP. The culture conditions were the same employed in the preliminary experiment. The number of explants per treatment was 20, the experiment was repeated twice. For the rooting and acclimatization steps the same protocol described bellow was followed.

\section{In vitro plant polyploidization}

Nodal segments from in vitro plant of $S$. montevidiensis var. montevidiensis were submerged in $1 \%$ DMSO solution containing the following doses of colchicine $(\mathrm{v} / \mathrm{v})$ : $0.0 ; 0.1$; $0.05 ; 0.01$ and $0.001 \%$ ( 24 and $48 \mathrm{hrs}$ ). As control treatments, a group of nodal segments was untreated, and other segment groups were submerged in water or in $1 \%$ DMSO (water solution). The number of explants per treatment was 15 . The culture medium was MS supplemented with $0.25 \mathrm{mg} / \mathrm{L}$ BAP. The culture conditions and the acclimatizing protocol were those mentioned in the above section.

The ploidy level was determined using the flow cytometer (Partec, CA), following the commercial indications, that is, approximately $0.5 \mathrm{~cm}^{2}$ of leaf tissue were chopped with a sharp razor blade submerged in $0.5 \mathrm{ml}$ nucleus extraction buffer (HR A solution, Partec, CA) and then incubated in the same buffer during $1.5 \mathrm{~min}$. After filtered, the solution was incubated 1 min with HR B, Partec, CA, (Sari et al. 1999; De Schepper et al. 2001). The different flow cytometer parameters were adjusted with non treated material to obtain well defined and reproducible readings.

Once established under greenhouse conditions, the recovered treated plants were phenotypically analyzed. The diameter of flowers and stems and the size of the leaves were gauged. For the flower diameter 12 well developed flowers were measured. The stem diameter was measured at the height of the third leaves pair. Also, the third leaves pair was chosen to measure the ratio length/ wide to establish the size of the leaves.

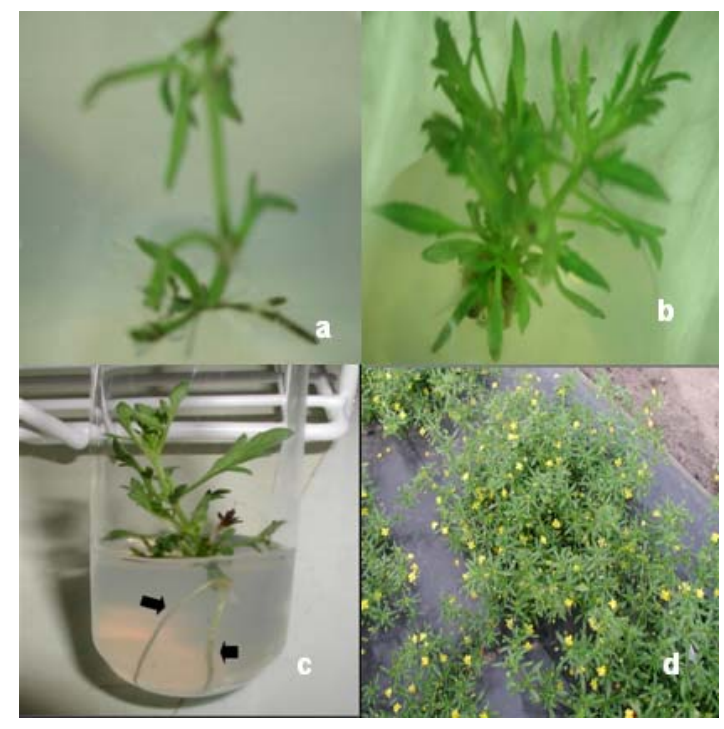

Figure 1. Development of S. montevidiensis tissue culture. (a) Early stage of the in vitro culture, explant: nodal segment with two nodes.

(b) Nodal segment showing shoots development (MS + $0.25 \mathrm{mg} / \mathrm{L}$ BAP).

(c) Well developed shoot in the rooting step (roots arrowed).

(d) Flowering ex vitro plants grown under greenhouse conditions. 
Table 2. Number of shoots per explants in five Scoparia species.

\begin{tabular}{|l|c|}
\hline \multicolumn{1}{|c|}{ Species } & \multicolumn{1}{|c|}{$\begin{array}{c}\text { No. of shoots } \\
(\text { mean } \pm \text { SD) }\end{array}$} \\
\hline S. dulcis & $12.0 \pm 2.7 \mathrm{a}$ \\
\hline S. hasleriana & $--{ }^{\mathrm{y}}$ \\
\hline S. montevidiensis var glandulifera & $10.4 \pm 2.5 \mathrm{a}$ \\
\hline S. montevidiensis var montevidiensis & $11.2 \pm 2.7 \mathrm{a}$ \\
\hline S. nudicaulis & $10.2 \pm 2.96 \mathrm{a}$ \\
\hline
\end{tabular}

MS medium supplemented with $0.25 \mathrm{mg} / \mathrm{l} \mathrm{BAP}$.

z Same letters in the column indicated no significant differences.

${ }^{y}$ No shoots were developed.

\section{Statistical analysis}

Statistical analysis was performed using ANOVA and Tukey test (95\%) supported by the software Statistica 2.0.

\section{RESULTS}

\section{Tissue culture}

Table 1 shows the results obtained with the nodal segments of $S$. montevidiensis var. glandulifera. In the treatments containing NAA (alone or combined with BAP), the callus induction was the main response of the culture. The treatments containing BAP alone and the hormone free treatment showed shoot development. Significant differences in the shoots multiplication rate were detected between the treatment containing $0.25 \mathrm{mg} / \mathrm{L}$ BAP $(9.04$ shoots/explant) and the other treatments. The treatment containing $1.0 \mathrm{mg} / \mathrm{L}$ BAP showed callus production and a very important tissue vitrification. In the treatments containing 0.5 and $0.25 \mathrm{mg} / \mathrm{L}$ BAP shoots and callus development were also detected. Although the callus production was important in the treatment with $0.5 \mathrm{mg} / \mathrm{L}$ BAP, no vitrification was detected in this treatment. Either callus formation and/or vitrification process were not found in the hormone free treatment. All the recovered shoots rooted in hormone free MS medium. The progress of the in vitro culture of $S$. montevidiensis var. glandulifera onto a MS medium supplemented with $0.25 \mathrm{mg} / \mathrm{L} \mathrm{BAP}$ is showed in Figure 1. Figure 1a shows the original explant, a disinfected nodal segment with two nodes at the early times of the culture. A well developed nodal segment showing several shoot and a very little callus development is showed in the Figure $1 \mathrm{~b}$. Figure 1c, shows a rooted shoot at the end of the in vitro culture, and the acclimated and flowering plants growth under greenhouse conditions is showed in Figure 1d.

\section{In vitro multiplication of five Scoparia accessions}

The responses of the five Scoparia accessions under the culture conditions proposed in the present work are showed in Table 2. Under the culture conditions tested, no significant differences were found between $S$. montevidiensis var. glandulifera, S. montevidiensis var. montevidiensis, $S$. dulcis and $S$. nudicaulis. In fact, the mean of shoots per explant for these species oscillated between 10.2 for $S$. nudicaulis and 12.0 for $S$. dulcis. The exception was $S$. hasleriana that showed little callus proliferation, followed by browning of the callus and ending with explants death under the assayed culture conditions.
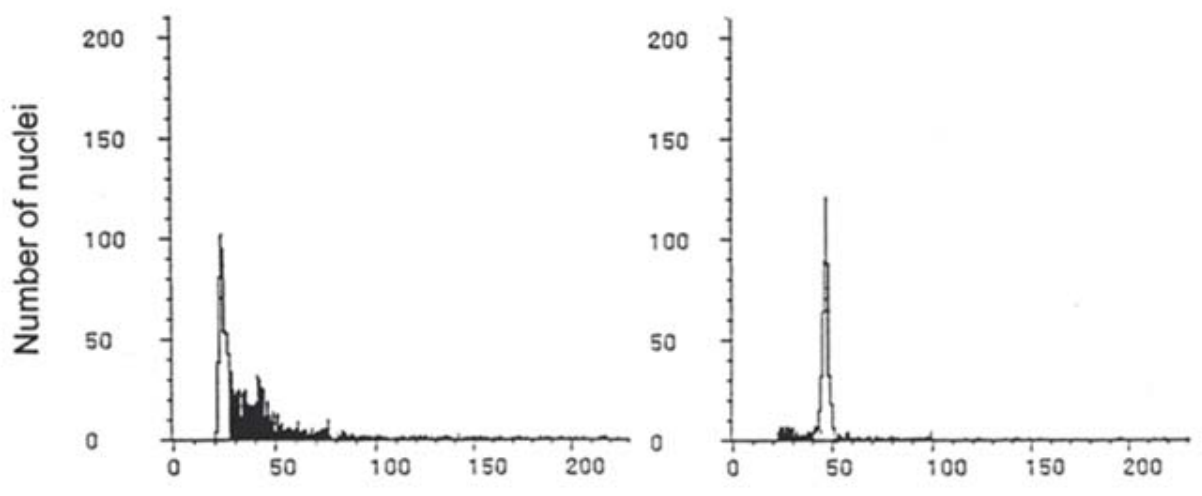

Relative fluorescence

Figure 2. Peaks obtained by the flow cytometry analysis of a colchicine treated plant (right), and an untreated colchicine control (left). The right peak mode is 47 , their mean is 46.59 and the variation coefficient: $2.68 \%$. For the left peak the mode was 23 . Their mean: 23.45 and the variation coefficient $5.33 \%$. 
Table 3. Number of shoots per explant and tetraploids or chimeric plants obtained through colchicine treatment in Scoparia montevidiensis

\begin{tabular}{|c|c|c|c|c|c|}
\hline \multicolumn{2}{|c|}{ Treatment } & \multirow{2}{*}{$\begin{array}{l}\text { No. of shoots per } \\
\text { explants } \\
(\text { mean } \pm S D)^{z}\end{array}$} & \multirow{2}{*}{$\begin{array}{l}\text { No. of plants } \\
\text { analyzed }\end{array}$} & \multicolumn{2}{|c|}{ No. of plants } \\
\hline Conc. of Colchicine (\%) & $\begin{array}{c}\text { Duration } \\
\text { (hours) }\end{array}$ & & & $2 X / 4 X$ & $4 X$ \\
\hline Control $1^{y}$ & --- & $11.16 \pm 1.16 a$ & 5 & 0 & 0 \\
\hline Control $2^{x}$ & 24 & $12.12 \pm 1.80 a$ & 10 & 0 & 0 \\
\hline Control $2^{\text {,x }}$ & 48 & $12.20 \pm 1.70 \mathrm{a}$ & 5 & 0 & 0 \\
\hline${\text { Control } 3{ }^{w}}^{w}$ & 24 & $11.00 \pm 1.41 \mathrm{a}$ & 5 & 0 & 0 \\
\hline Control 3' w & 48 & $11.17 \pm 1.16 a$ & 5 & 0 & 0 \\
\hline 0.001 & 24 & $11.00 \pm 2.44 \mathrm{a}$ & 50 & 3 & 2 \\
\hline 0.001 & 48 & $12.50 \pm 2.07 \mathrm{a}$ & 24 & 1 & 1 \\
\hline 0.01 & 24 & $9.57 \pm 1.71 \mathrm{a}$ & 35 & 1 & 0 \\
\hline 0.01 & 48 & $10.71 \pm 1.97 a$ & 40 & 1 & 0 \\
\hline 0.05 & 24 & $9.00 \pm 3.34 a$ & 60 & 6 & 1 \\
\hline 0.05 & 48 & $9.87 \pm 2.79 a$ & 40 & 2 & 0 \\
\hline 0.1 & 24 & $6.85 \pm 2.41 \mathrm{~b}$ & 50 & 1 & 0 \\
\hline 0.1 & 48 & $6.57 \pm 1.51 b$ & 70 & 0 & 0 \\
\hline \multicolumn{2}{|l|}{ Total } & & 379 & 15 & 4 \\
\hline
\end{tabular}

Same letter indicates no significant differences.

${ }^{y}$ Untreated plants.

${ }^{x}$ Water treatment

${ }^{\mathrm{w}}$ DMSO treatment.

\section{In vitro plant polyploidization}

Complete and viable plants of $S$. montevidiensis var. montevidiensis were recovered after the colchicine treatment. Table 3 shows the means of shoot per explant obtained from the different colchicine treatments. Except for the treatments $0.1 \%$ colchicine, 24 and $48 \mathrm{hrs}$, the others treatments oscillated from 9.0 shoots/explants $(0.05 \%$ colchicine $/ 48 \mathrm{hrs})$ to 12.12 (water control) and no significance differences were found between them. The unique treatments showing significant differences in relationship with the controls were those with the $0.1 \% 24$ and 48 hrs colchicine doses, the means of these treatments were 6.85 and 6.57 respectively. The number of flow citometry analyzed plant, the number of chimeric (2X/4X) plants detected and the solid tetraploid (4X) plants obtained by colchicine treatment with $S$. montevidiensis var. montevidiensis are also showed in Table 3. From a total of 379 analyzed plants, 15 chimeric plants were detected among all colchicine treatments except from the dose $0.1 \% / 48 \mathrm{hrs}$. A total of four solid tetraploid plants were detected, two with the $0.001 \% / 24 \mathrm{hrs}$ colchicine dose, one with the $0.001 \% / 48 \mathrm{hrs}$ dose and the last one with $0.05 \% / 24$ hrs dose. Figure 2 shows an example of peak reading obtained by flow citometry analysis, the right peak of Figure 2a indicates that the mean of relative DNA content for the colchicine treated plant is 46.59 , being their mode 47 and a variation coefficient of $2.68 \%$, for a total of 625 cells counted $(15,015$ cells $/ \mathrm{mL})$. The left peak (Figure 2) shows the reading obtained for the untreated material, in this case the mean of relative DNA content was 23.45 and their mode was 23 with a variation coefficient of $5.33 \%$, for a total of 1,231 cells counted $(29,810$ cells $/ \mathrm{mL})$.
Figure $3 \mathrm{a}, \mathrm{b}, \mathrm{c}$ compares the appearance of the tetraploid and diploid plants. It is possible to observe differences in the foliage (Figure 3a), being more abundant those of the tetraploid plant (arrowed). The Figure $3 b$ shows the different sizes of a tetraploid flower (arrowed) and a diploid one. In the upper lane of Figure $3 \mathrm{c}$ are tetraploid leaves that showed to be larger than the diploid ones (Figure 3c, lower lane). The Figure $3 \mathrm{~d}$ shows a flowering tetraploid plant with an interesting relationship flower/foliage.

The differences measured between the organs of tetraploids and diploid plants are showed in Table 4.

All the analyzed traits (diameter of stem and flower and leaf size) showed clearly that the tetraploid plant named as S1 was significantly larger than both, the tetraploid S3 and the control plant, being the means of the leaf size (234.27 $\mathrm{mm}^{2}$ for S1, $99.19 \mathrm{~mm}^{2}$ for $\mathrm{S} 3$ and $22.4 \mathrm{~mm}^{2}$ for the control one) the variable that showed more dramatic differences among the analyzed plants.

\section{DISCUSSION}

Chromosome duplication or polyploidy, a common phenomenon in ornamental species (Horn, 2002), is associated with an enlargement of organs (flowers and leaves), an intensification of colours, hardier and more robust plants, thicker and more rigid foliage, an apparent increase in the tolerance to different stresses, and the resistance to diseases and pests (Petit and Callaway, 2000). For this reason poliploidization is recognized as a source of evolution and domestication of flowering plants (Van Tuyl and Lim, 2003). 
Table 4. Comparisons of some morphological characteristics between diploid and tetraploid S. montevidiensis.

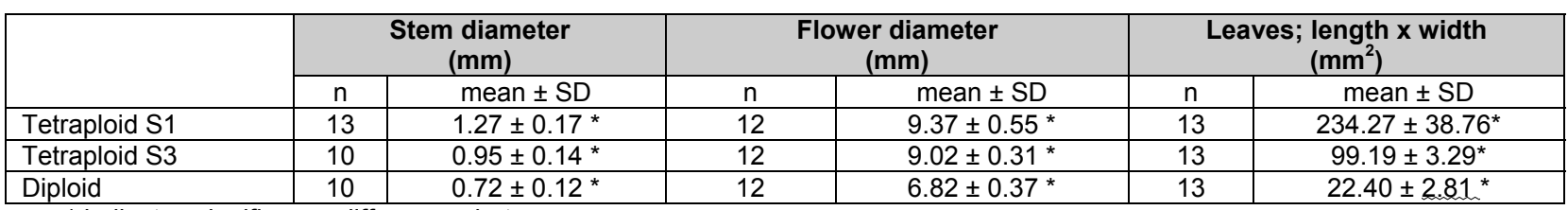

* indicates significance differences between means.

Chromosome duplication is caused by abnormalities during mitosis and it may occur spontaneously in most plants. Although, these disruptions during cell division can be artificially induced with colchicine and thus, in vitro polyploidization was proposed back in the 1960's as an alternative tool to obtain polyploid plants (Murashige and Nakano, 1966). This methodology was extensively used during the last 30 years in many species such as banana (Baziran and Ariffin, 2002), grapes (Notsuka et al. 2000), blueberry (Lyrene and Perry, 1982), potato (Hermsen et al. 1981), and sugarcane (Heinz and Mee, 1970). Under in vitro controlled conditions polyploidization was applied in several ornamental crops, such as Alocasia (Thao et al. 2003), Rhododendron (Väinölä, 2000; Eeckhaut et al. 2002), Cyclamen (Ishizaka and Uematsu, 1994; Takamura and Miyajima, 1996).

To start with the in vitro polyploidization experiments, the appointment of in vitro micropropagation is required as the first step. The tissue culture experiment in this study showed that Scoparia monteviediensis presents strict hormonal and nutritional requirements. Although the addition of NAA induced callus proliferation in all treatments regardless of BAP concentration, the latter had an apparent impact on the calli aspect. In BAP concentrations up to $0.25 \mathrm{mg} / \mathrm{L}$, calli were compact whereas with concentrations of $0.25 \mathrm{mg} / \mathrm{L}$ BAP and in BAP free media, calli were friable. In the hormone free treatments and those with BAP alone, shoots production was the main response of the explants. In this case, multiplication rate varied with BAP concentration, having obtained the best response with $0.25 \mathrm{mg} / \mathrm{L}$ BAP (9 shoots/explant). An increment of the citocinine, not only did not improved the multiplication rate, but also induced callus proliferation. At BAP concentrations of $1.0 \mathrm{mg} / \mathrm{L}$ BAP, a very important tissue vitrification was observed.

Scoparia spp. rooted easily using the proposed protocol, even with the previous BAP treatment. This, together with the fact that no problems were found either in the acclimatization step, or in the multiplication rate, indicates that this material is suitable for commercial multiplication.

When the protocol proposed for S. motevidiensis was tested with the other Scoparia species, only S. hasleriana did not present a good response. In the same way, satisfactory results were obtained using the same conditions applied here with other Scrophulareaceae genus (data not shown). These results represent an important start point for the evaluation of other Scrophulariaceae species for in vitro shoot multiplication that will contemplate a careful adjustment of BAP concentration to avoid undesirable results such as callus proliferation and/or vitrification process, with no addition of NAA.

There are different alternative techniques to get in vitro polyploid plants. For Rhododendron simsii, Eeckhaut et al. (2002) reported a treatment using a drop of colchicine solution placed between the cotyledons daily during either 3 or 7 days in a 3 weeks seedling obtained in vitro. Takamura and Miyajima (1996) inoculated the tuber sections of Cyclamen persicum by submersion in colchicine solution without shaking for 1, 2, 4 and 7 days. Väinölä (2000) tested successfully an in vitro polyploidization protocol of microshoots of Rhododendron hybrids with synchronized growth by submersion and shaking in different concentration of colchicine solutions.

In the present study the tissue culture experiments showed that Scoparia genus has a good response under the in vitro conditions applied, generating several shoots from one nodal segment, even in the hormone free medium ( 2.25 shoots/explant). Consequently, when using explants from in vitro plantlets with actively growing meristems the

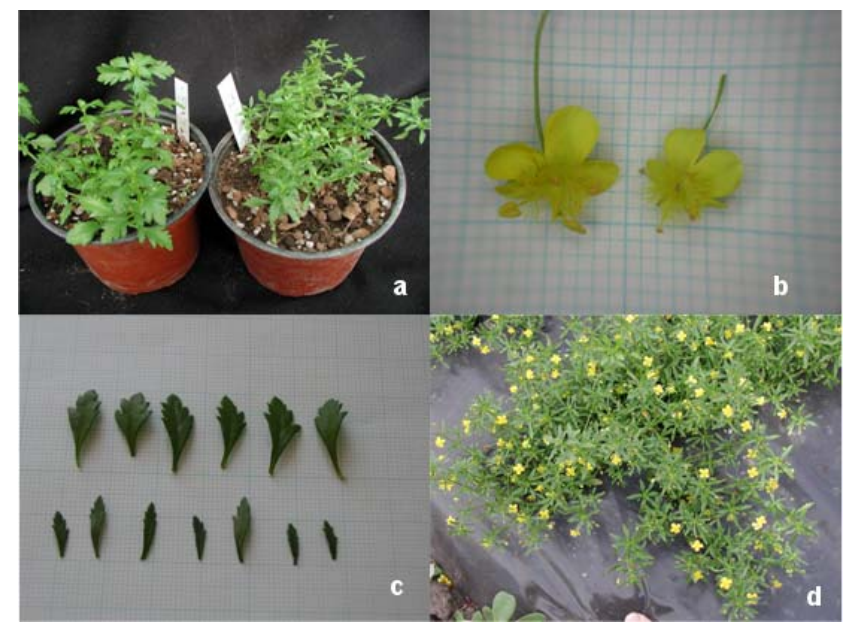

Figure 3. Comparison of morphological characteristics of flowers and leaves between tetraploid and diploid in $S$. montevidiensis.

(a) Tetraploid plant (arrowed) and diploid one.

(b) Different sizes of a tetraploid flower (arrowed) and a diploid one.

(c) A sample of tetraploid leaves (upper lane) and diploid ones (lower lane). 
recovering of polyploid individuals is expected.

All the recovered plants (diploid, chimaeric and tetraploid plants) showed the same behaviour during the different stages of the in vitro multiplication protocol.

Under the conditions tested, the colchicine treatment of $0.05 \% / 48 \mathrm{hrs}$ seems to be the maximum dose that did not affect the regeneration capacity of the $S$. montevidiensis var. montevidiensis nodal segments. In fact, no significant differences were found between the average of shoots per explant of the control and the mentioned treatment. But when the explants were exposed to a colchicine solution of $0.1 \%$ during 24 and $48 \mathrm{hrs}$, the multiplication rate diminished significantly from 12.12 shoots per explant for the control 2, to a value of 6.57 shoots per explant for the treatment $0.1 / 48$. In the same way, in all treatments chimaeric and/or solid tetraploid individuals were recovered, the exceptions were doses where all the recovered shoots were diploid. It is possible that at this colchicine concentrations the damage induced by the alkaloid was turning the affected shoots non viable.

The variation coefficients obtained in the analysis of the ploidy of the peak readings of the Figure 2 shows clearly the difference of the DNA amount between the tetraploid plant and their control.

The diameter of stem and flower and leaf size showed in Table 4 are in agreement with descriptions in Figure 3. In fact, the two tetraploid plants morphologically studied showed significant differences between them and with the control. If it is taken into account that in our experiment all the initial explants come from the same accession, it is possible suggest that the two tetraploid plants may differ in chromosome number.

The present study is the first report of the application of this biotechnological methodology in Scoparia genus. Tissue culture combined with the polyploidization treatment showed to be a very interesting alternative to obtain the needed variability in Scoparia genus to start a breeding program.

\section{ACKNOWLEDMENTS}

We thank to Carlos Greco and Alberto Acevedo for their critical revision of the manuscript and their suggestions. Also we thank to Sara Ostertag and Martin Saragoiti for their technical support.

\section{REFERENCES}

BAZIRAN, N. and ARIFFIN, S. The progress and potentials of mutation induction in vegetatively propagated plants in Malaysia. Malaysian Institute for Nuclear Technology Research (MINT) [cited 26 September 2003] Portable Document Format. Available from Internet: http://www.fnca.jp/english/fnca/2_totuzenheni/3/2002ws/0 4/04malasya/main.html.
DE SCHEPPER, S.; LEUS, L.; MERTENS, M.; VAN BOCKSTAELE, E. and DE LOOSE, M. Flow cytometric analysis of ploidy in Rhododendron (subgenus Tsutsusi). HortScience, 2001, vol. 36, no. 1, p. 125-127.

EECKAUT, T.; SAMSYN, G. and VAN BOCKSTAELE, E. In vitro polyploidy induction in Rhododendron simsii hybrids. Acta Horticulturae, 2002, vol. 572, p. 43-49.

ESCANDÓN A.S.; FERRARI, P.; FACCIUTO, G.; SOTO, S.; HAGIWARA, J.C. and ACEVEDO, A. Combinación de técnicas in vitro y ex vitro para la micropropagación de Santa Rita (Hibr.). Una arbustiva de relevancia ornamental. Revista de Investigaciones Agropecuaria, April 2003, vol. 32, no. 1, p. 111-122.

HEINZ, D.J. and MEE, G.W.P. Colchicine-induced polyploids from cell suspension cultures of sugarcane. Crop Science, 1970, vol. 10, p. 239-246.

HERMSEN, J.G.; RAMANNA, M.S.; ROEST, S. and BOCKELMANN, G.S. Chromosome doubling through adventitious shoot formation on in vitro cultivated leaf explant from diploid interespecific potato hybrids. Euphytica, 1981, vol. 30, no. 2, p. 239-246.

HORN, W. Breeding for Ornamentals. In: VAINSTEIN, A. ed. Classical and Molecular Approaches. Kluwer Academic Publisher, Netherlands, 2002, p. 47-83.

ISHIZAKA, H. and UEMATSU, J. Amphidiploids between Cyclamen persicum Mill. and $C$. hederifolium Aiton induced through colchicine treatment of ovules in vitro. Breeding Science, 1994, vol. 44, no. 2, p. 161-166.

LYRENE, P. and PERRY, J.L. Production and selection of blueberry polyploid in vitro. Journal of Heredity, 1982, vol. 73, p. 377-378.

MURASHIGE, T. and NAKANO, R. Tissue culture as a potential tool in obtaining polyploid plants. Journal of Heredity, 1966, vol. 57, p. 114-118.

MURASHIGE, T. and SKOOG, F. A revised medium for rapid growth and bioassays with tobacco tissue cultures. Physiolgia Plantarum, 1962, vol. 15, p. 437-497.

NOTSUKA, K.; TSURU, T. and SHIRAISHI, M. Induced polyploidy in grapes via in vitro chromosome doubling. Journal of Japan Society of Horticulture Science, 2000, vol. 69 , no. 5, p. 543-551.

PETIT, T.L. and CALLAWAY D.J. Breeding daylilies (Hemerocallis). In: CALLAWAY, D. and CALLAWAY, M.B. eds. Breeding Ornamental Plants. Timber Press, Portland, Oregon USA, 2000, p. 49-73.

SARI, N.; ABAK, K. and PITRAT, M. Comparison of ploidy level screening method in watermelon: Citrullus 
Escandón, A. et al.

lanatus (Thunb.) Matsum and Nakai. Scientia Horticulturae, 1999, vol. 82, no. 3-4, p. 265-277.

TAKAMURA, T. and MIYAJIMA, I. Colchicine induced tetraploids in yellow-flowered cyclamens and their characteristics. Scientia Horticulturae, 1996, vol. 65, no. 4, p. 305-312.

THAO, N.T.P.; URESHINO, K.; MIYAJIMA, I.; OZAKI, $\mathrm{Y}$. and OKUBO, H. Induction of tetraploids in ornamental Alocasia through colchicine and oryzalin treatments. Plant Cell Tissue and Organ Culture, 2003, vol. 72, no. 1, p. 1925.

VÄINÖLÄ, A. Polyploidization and early screening of Rhododendron hybrids. Euphytica, 2000, vol. 112, no. 3, p. 239-244.

VAN TUYL, J.M. and LIM, KI-BYUNG. Interspecific hybridization and polyploidization as tools in ornamental plant breeding. Acta Horticulturae, 2003, vol. 612, p. 1322 .

ZULOAGA, F.O. and MORRONE, O. Catálogo de Plantas Vasculares de la República Argentina. In: Monographs in Systematic Botany from the Missouri Botanical Garden.Missouri Botanical Garden Press, 1999, vol. 74, p. 1037-1038. ISBN 0-915279-65-7. 